\title{
Assessment of Traffic Noise Pollution in Traffic Agents
}

\author{
Maria do Socorro Oliveira Soares ${ }^{1}$, Karla Geovanna Moraes Crispim ${ }^{2}$, Aldo Pacheco Ferreira ${ }^{3 \text {,* }}$ \\ ${ }^{1}$ Workers'Health Referral Center (CEREST/Manaus/Amazonas State) and Amazonas State University \\ ${ }^{2}$ Leonidas and Maria Deane Research Center/ILMD/Fiocruz \\ ${ }^{3}$ SérgioArouca National School of Public Health/ENSP/Fiocruz \\ *Corresponding author (Email: aldopachecoferreira@gmail.com)
}

\begin{abstract}
Traffic noise is an important source of environmental annoyance. Severe annoyance persistent over prolonged periods of time is to be regarded as causing distress. The Noise-Induced Hearing Loss (NIHL) as a change of sensorineural hearing thresholds resulting from exposure to high sound pressure levels for long periods, sometimes years, presents an irreversible and progresses gradually with time-varying risk exposure, usually, bilateral. This study describes the audiological profile of traffic agents who worked on public streets in Manaus/AM, exposed to sound pressure levels. The applied research design was a retrospective cross-sectional study in 118 traffic agents, analyzing their auditory performance, with audiometric tests and a structured questionnaire. The results show a prevalence of NIHL of 20.5\% in RE (right ear), and 19.2\% in the LE (left ear). The comparison between sequential tests of reference points a significant change in hearing threshold after occupational exposure. Correlation was observed with variables: age, working time, use of personal protective equipment, and extra-auditory complaints. The results suggest that occupational exposure related to urban noise is associated with hearing loss and other extra-auditory symptoms, denoting the urgency of public policies.
\end{abstract}

Keywords - Traffic Agents, Noise Pollution, Hearing Loss, Occupational, Annoyance, Public Health

\section{Introduction}

The advancement of technology led improvement the quality of life and well-being of society, however, this technological development has brought consequences such as environmental pollution (Ferreira Jr., 1998; Minayo et al., 2000). Environmental noise pollution is a threat to health and quality of people's lives. It is more severe and widespread than ever before, and it will continue to increase in magnitude and severity because of population growth, urbanization, and the associated growth in the use of increasingly powerful, varied, and highly mobile sources of noise. It will also continue to grow because of sustained growth in highway, rail, and air traffic, which remain major sources of environmental noise (Welch et al., 2013).

Noise pollution is considered a risk to health and quality of life, being its effects as hearing loss, communication difficulties, pain, interference with sleep, clinical effects on general health and on the implementation tasks, and other annoyances nonspecific effects (WHO, 1999). The World Health Organization (WHO) defines disabling hearing impairment in adults as a permanent hearing threshold level of 41 decibels $(\mathrm{dB})$ or greater (Table 1). This is based on the unaided hearing threshold in the better ear and is averaged over the $0.5,1,2$, and 4 $\mathrm{kHz}$ frequencies. A hearing threshold level of $41-60 \mathrm{~dB}$ is considered moderate impairment and the beginning of disabling hearing impairment because, at this level of impairment, an individual is able to distinguish words spoken at one meter only if they are spoken in a raised voice (WHO, 1991). Hearing aids are usually required at this level of impairment (WHO, 2009). In contrast, the WHO defines a hearing threshold level of 26-40 dB as 'slight impairment' as the individual can distinguish normally-voiced words spoken at one meter (WHO, 2009).

Table 1. WHO Grades of Hearing Impairment

\begin{tabular}{|c|c|l|}
\hline Grade & Hearing level(a) & \multicolumn{1}{|c|}{ Impairment } \\
\hline 0 & $\leq 25 \mathrm{~dB}$ & None - can hear whispers \\
\hline 1 & $26-40 \mathrm{~dB}$ & $\begin{array}{l}\text { Slight - can hear words at 1m in normal } \\
\text { voice }\end{array}$ \\
\hline 2 & $41-60 \mathrm{~dB}$ & $\begin{array}{l}\text { Moderate - can hear words at 1m in } \\
\text { raised voice }\end{array}$ \\
\hline 3 & $61-80 \mathrm{~dB}$ & $\begin{array}{l}\text { Severe - can hear words if shouted into } \\
\text { ear }\end{array}$ \\
\hline 4 & $\geq 80 \mathrm{~dB}$ & Profound - cannot hear shouted words \\
\hline
\end{tabular}

(a) Averaged over $0.5,1,2,4 \mathrm{kHz}$ in better ear

Source: WHO (2009)

Noise-induced hearing loss (NIHL) is a sensorineural hearing deficit that begins at the higher frequencies (3.000 to $6.000 \mathrm{~Hz}$ ) and develops gradually because of chronic exposure to excessive sound levels. Although the loss is typically 
symmetric, noise from such sources as traffic noise may produce an asymmetric loss (Caciari et al., 2013; Cordeiro et al., 2005). Acoustic trauma, a related condition, results from an acute exposure to short-term impulsive noise. NIHL has been well recognized since the industrial revolution, and in today's noisy society is the second most common sensorineural hearing loss, after age-related hearing loss (presbycusis). The economic cost of occupational hearing loss has been estimated to be billions of dollars. Moreover, NIHL can begin immediately or gradually and may be temporary or permanent. Depending on the intensity of the noise and the duration of exposure, hearing loss can range from a small shift in the threshold at which sounds at different frequencies can be detected to total deafness. Hearing loss may affect one or both ears, although not always to the same extent (Botteldooren $e t$ al., 2011).

The development of urban areas results in major environmental manipulation, which causes changes in the landscape, in the community, in the psychological and physiological state inhabitants, besides yielding cultural factors, both economic and political which, individually or collectively influence or determine the quality of life that resides there. One form of pollution that can cause serious effects on the quality of life for humans and the environment as a whole is noise pollution (Forattini, 1991; Gozalo et al., 2013).

Noise can cause harmful effects to the human body, which could be hearing, when the action is directly on the auditory system, creating difficulties in communication, or extra-auditory where physiological functions are affected, such as sleep, blood pressure, causing physical and mental fatigue (Nunes, 2006). Exposure to continuous noise of 85-90 dBA, particularly over a life time in urban traffic, can lead to a progressive loss of hearing, with an increase in the threshold of hearing sensitivity. Hearing impairments due to noise are a direct consequence of the effects of sound energy on the inner ear (Stansfeld\&Matheson, 2003).

Traffic noise is considered a major contributor to noise pollution (Botteldooren et al., 2011). Arguably, the major cities have unfavorable acoustic characteristics resulting from intense urbanization and high concentration of vehicles on public roads (Azevedo, 1993; Nunes, 2006). Between 2001 and 2009, in Brazil there was an increase of more than 24 million cars, trucks, motorcycles and other vehicles - an increase of $76 \%$ in the total fleet. Some of the biggest Brazilian cities, however, the increase were much higher. Manaus in 2001 had its fleet estimated at 185,647, and in 2009 reached 383,933 , an increase of $106 \%$. Currently, it is the capital of the Northern Region with the largest fleet of vehicles. 516,632 vehicles are circulating in this city, according actual data from Amazonas State Traffic Department. Moreover, the noise may cause the workers and autonomic reactions such alarm reaction whose effects and consequences in the life of the individual can be identified from circulatory disorders, gastrointestinal, interfering with the skills, changes in sleep and concentration. Thus, it is more difficult to think and concentrate in noisy places, being the work in these spaces potentially more stressful, with a decrease in revenue due to the effort made in the execution of tasks (Oliveira\& Lisbon, 2007).

Among all the factors or agents that are at occupational risk, certainly, noise appears as the most frequent, most universally distributed, and therefore, that exposes a greater number of workers. Traffic agents, who conduct their activities on public streets, constitute a population at risk to changes or affect that noise, can affect health in general (Barregard $e t$ al., 2009). They worked in shifts on parking, patrols, keeping passage-ways free, and controlling traffic at crossings and on roads with intense flows of traffic. At the end of a workday, this worker may have pathological ear fatigue, characterized by temporary or permanent reduction in hearing ability (Gozalo et al., 2013).

The main objective of the study was to assess the traffic noise pollution in traffic agents and its health effect, and evaluate the environmental noise levels in Manaus, Amazonas State, Brazil.

\section{Subjects and Methods}

\subsection{Study site}

Manaus (Coordinates: $03^{\circ} 06^{\prime} 0^{\prime \prime} \mathrm{S} 60^{\circ} 01^{\prime} 0^{\prime \prime} \mathrm{W}$ ) is situated at the confluence of Negro and Solimões rivers (Figure 1). Is the largest metropolitan in northern Brazil and the eleventh in all of Brazil, with 2,283,906 inhabitants. The population in 2012 was 1.85 million people; it is the most populous city in North Regionand seventh most populous city of Brazil. Currently, the city is one of 12 most influential cities of the country. Alone represents $10.89 \%$ of the population of the whole of northern Braziland $49.9 \%$ of the population of Amazonas State (IBGE, 2012).

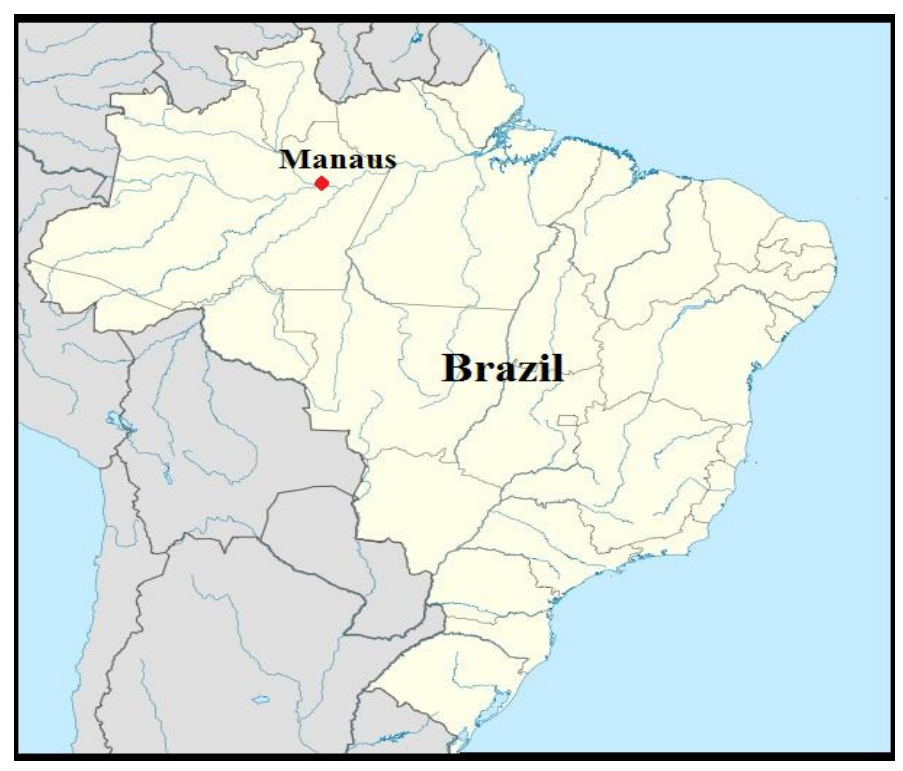

Fig. 1. Study Area: Manaus, Amazonas State, Brazil

\subsection{Research Tool}

The baseline survey was conducted between March and De- 
cember 2011. The sample consisted of 118 traffic agents who worked on public roads at least 3 years, and associated to Municipal Institute of Traffic Engineering and Control (MANAUSTRANS). This institute has the competence to plan, design, operate and regulate the traffic.

The applied research design was a retrospective cross-sectional study in 118 traffic agents, analyzing their auditory performance, with audiometric tests and a structured questionnaire. An occupational audiologic anamnesis was carried out, with questions referring to general and hearing health history, lifestyle and occupational history (Bernardi, 2003). Subsequently, pure tone audiometry and speech perception tests were performed. The conventional audiological assessment was comprised by the following procedures: i) Visual inspection of the external acoustic canal with Heine otoscope; ii) Acoustic immittance measures (tympanometry and research of the ipsilateral acoustic reflexes in the frequencies of 500, 1000, 200 and $400 \mathrm{~Hz}$ ) with a Grason-Stadler GSI-33 middle ear analyzer (ANSI s3.39-1987); and iii) Pure tone audiometry (frequencies from 250 to $8000 \mathrm{~Hz}$ ), speech recognition threshold (SRT) and speech recognition index (SRI) with GSI-61 and GSI-68 Grason-Stadler audiometers, supra aural hearing phones TDH-50 (ANSI S3.1989 and IEC-1988) and a soundproof booth (ANSI S3.1-1991).

The results of the audiometry were analyzed according to the Ordinance of the Ministry of Labour No.19 (1998). Based on this Ordinance, is considered within the normal range, the cases whose audiogram shows hearing thresholds less than or equal to $25 \mathrm{~dB}$ at all frequencies examined. It is considered suggestive of NIHL, cases where audiogram at frequencies 3000 and / or 4000 and / or $6000 \mathrm{~Hz}$ presenting thresholds greater than $25 \mathrm{~dB}$, both in test of Air Conduction (AC) as Bone Conduction (BC), in one or both side are considered other causes, cases whose audiogram does not fit the descriptions previously described.

During preliminary meeting for the research, the participants had the presentation of research proposal, information about the procedures involved and the invitation to participate. Participation in the study was formalized through the signing of the consent form. Criteria used for the inclusion of the participants were: at least 3 years at work; absence of general health deficits; negative screening results for hearing, voice, speech, and language; signing the informed consent form in person; declare to be able and interested in participating in research study. The interviews were done by the mainly researcher.

\subsection{Statistics}

Statistical tests were performed using Statistica 8.0 (StatSoft $\left.{ }^{\prime}\right)$.

\subsection{Ethical aspects}

The ethical aspects were respected to the Diretrizes and Normas Regulamentadoras - 466/2012 resolution, through a Free Informed Consent Term and by the consent of the Institution Ethical Committee (Amazonas State University), 254/10-CEP/UEA.

\section{Results}

Related to the study population distribution, the research had the participation of 118 subjects, distributed in 95 males and 23 females, aged $26-63$ years old, average 38.29 years. Time function working ranged in 3-20 years, average 8.39 years, with $(49.1 \%)$ concentrated between 6-10 years.

Table 2 indicates the relationship between the use of hearing protectors and self-reported hearing. The total subjects who reported hearing bad, $1.7 \%$ makes use of personal protective equipment and 5.2\% does not. Of those who reported regular hearing, $27.6 \%$ do not use hearing protection. Despite the significant noise exposure, with about $90 \mathrm{~dB}$ in average at peak hours, only $50.8 \%$ use of hearing protectors.

Table 2. Effects by the Use of Hearing Protector and Self-Perception of Hearing on Traffic Agents, Manaus 2011

\begin{tabular}{|c|c|c|c|c|c|c|}
\hline \multicolumn{2}{|c|}{$\begin{array}{c}\text { Use of } \\
\text { hearing } \\
\text { protector }\end{array}$} & \multicolumn{5}{|c|}{ Self-perception of hearing } \\
\hline \multirow{3}{*}{ No } & \multirow{3}{*}{$\mathbf{R E}$} & Good & Regular & Bad & $\begin{array}{l}\text { Don't } \\
\text { know }\end{array}$ & Total \\
\hline & & $\begin{array}{c}34 \\
(58.6 \%)\end{array}$ & $16(27.6 \%)$ & $\begin{array}{c}3 \\
(5.2 \%)\end{array}$ & $\begin{array}{c}5 \\
(8.6 \%)\end{array}$ & \multirow{2}{*}{$\begin{array}{c}58 \\
(49.2 \%)\end{array}$} \\
\hline & & $\begin{array}{c}32 \\
(55.2 \%) \\
\end{array}$ & $17(29.3 \%)$ & $\begin{array}{c}4 \\
(6.9 \%)\end{array}$ & $\begin{array}{c}5 \\
(8.6 \%)\end{array}$ & \\
\hline \multirow[b]{2}{*}{ Yes } & \multirow[b]{2}{*}{$\mathbf{L E}$} & $33(55 \%)$ & $21(35 \%)$ & $\begin{array}{c}1 \\
(1.7 \%)\end{array}$ & $\begin{array}{c}5 \\
(8.3 \%)\end{array}$ & \multirow{2}{*}{$\begin{array}{c}60 \\
(50.8 \%)\end{array}$} \\
\hline & & $\begin{array}{c}34 \\
(56.7 \%)\end{array}$ & $20(33.3 \%)$ & $\begin{array}{c}1 \\
(1.7 \%)\end{array}$ & $\begin{array}{c}5 \\
(8.3 \%)\end{array}$ & \\
\hline & & & & & & 118 \\
\hline
\end{tabular}

Table 3 shows the distribution of audiometric test results. It's observed in standard exams, predominance of normal exams in both ears $(92.3 \%$ - RE and $86.5 \%$ and LE), and higher prevalence of NIHL in LE (12.5\%) than in RE (6.7\%). The sequential tests show increased prevalence of NIHL (20.5\%) in the RE, and (19.2\%) in the LE, suggesting significant change in hearing threshold after occupational exposure. 
Table 3. Tone Audiometric Threshold Data Obtained in the Study Population, Manaus 2011

\begin{tabular}{|c|c|c|c|c|}
\hline \multicolumn{2}{|c|}{ Evolutionary control } & Acceptable limits & $\begin{array}{c}\text { Case suggestive of } \\
\text { NIHL }\end{array}$ & $\begin{array}{c}\text { Case non-suggestive of } \\
\text { NIHL }\end{array}$ \\
\hline \multirow{2}{*}{ RE } & standard exams & 96 & 7 & 1 \\
\cline { 2 - 5 } & prevalence & $92.3 \%$ & $6.7 \%$ & $1 \%$ \\
\hline \multirow{2}{*}{ LE } & standard exams & 90 & 13 & 1 \\
\cline { 2 - 5 } & prevalence & $86.5 \%$ & $12.5 \%$ & $1 \%$ \\
\hline \multirow{2}{*}{$\mathrm{RE}$} & sequential exams & 60 & 16 & 2 \\
\cline { 2 - 5 } & prevalence & $76.9 \%$ & $20.5 \%$ & $2.6 \%$ \\
\hline \multirow{2}{*}{ LE } & sequential exams & 62 & 15 & 1 \\
\cline { 2 - 5 } & prevalence & $79.5 \%$ & $19.2 \%$ & $1.3 \%$ \\
\hline
\end{tabular}

Table 4 demonstrates the correlation between NIHL and length of service in the function. We observe a significant association between length of service in the function and hearing loss, with $18.8 \%$ (RE) and $13.4 \%$ (LE) of NIHL in 3-5 years of work, reaching to $37.63 \%$ (RE) and $33.4 \%$ (LE) over 11 years of work $(p=0)$.

Table 4. Correlation between NIHL and Length of Service in the Function in Traffic Agents, Manaus 2011

\begin{tabular}{|c|c|c|c|c|c|}
\hline \multirow{2}{*}{$\begin{array}{c}\text { Case suggestive of } \\
\text { NIHL }\end{array}$} & \multirow{2}{*}{ Variables } & \multicolumn{2}{|c|}{ Length of service in the function } & \multirow{2}{*}{ Total } \\
\cline { 3 - 6 } & & $\mathbf{3 - 5}$ years & $\mathbf{6 - 1 0}$ years & $\mathbf{1 1 - 2 0}$ years & \\
\hline \multirow{2}{*}{$\mathrm{RE}$} & years & 3 & 7 & 6 & 16 \\
\cline { 2 - 6 } & prevalence & $18.8 \%$ & $43.8 \%$ & $37.6 \%$ & $100 \%$ \\
\hline \multirow{2}{*}{ LE } & years & 2 & 8 & 5 & 15 \\
\cline { 2 - 6 } & prevalence & $13.4 \%$ & $53.3 \%$ & $33.4 \%$ & $100 \%$ \\
\hline
\end{tabular}

The mean of hearing thresholds frequencies of $3 \mathrm{kHz}, 4$ $\mathrm{kHz}$ and $6 \mathrm{kHz}$, as well as $500 \mathrm{~Hz}, 1000 \mathrm{~Hz}$ and $2000 \mathrm{~Hz}$ for the reference tests and sequential of both ears were grouped into four pairs for statistical analysis. Considering the result of the test, at $5 \%$ significance, there is difference between the mean hearing thresholds recorded on the standard and sequential exams. That is, on average the hearing thresholds at high frequencies in sequential examination $(21.84 \mathrm{~dB})$ at $\mathrm{RE}$, and $(21.67 \mathrm{~dB})$ at LE is greater than in the standard exam $(15.78 \mathrm{~dB})$ at RE, and $(16.16 \mathrm{~dB})$ at $\mathrm{LE}(p \leq 5 \%)$. Despite being an average threshold acceptable, it's observed that there was lowering on the threshold, a difference for more than $5 \mathrm{~dB}$ for both ears (Table 5).

Table 5. Results of the Paired T-Test between Hearing Thresholds in Standard and Sequential Exams Reported by the Traffic Agents, Manaus 2011

\begin{tabular}{|c|c|c|c|}
\hline Pair & Exam & Mean & t-test \\
\hline \multirow{2}{*}{$\begin{array}{l}1^{\circ} \text { pair RE } \\
300040006000 \mathrm{~Hz}\end{array}$} & Standard & 15.785 & \multirow{2}{*}{-6.666} \\
\hline & Sequential & 21.848 & \\
\hline \multirow{2}{*}{$\begin{array}{l}2^{\circ} \text { pair LE } \\
50010002000 \mathrm{~Hz}\end{array}$} & Standard & 12.633 & \multirow{2}{*}{-9.722} \\
\hline & Sequential & 19.696 & \\
\hline \multirow{2}{*}{$\begin{array}{l}3^{\circ} \text { pair LE } \\
\qquad 300040006000 \mathrm{~Hz}\end{array}$} & Standard & 16.165 & \multirow{2}{*}{-6.736} \\
\hline & Sequential & 21.671 & \\
\hline \multirow{2}{*}{$\begin{array}{l}4^{\circ} \text { pair RE } \\
50010002000 \mathrm{~Hz}\end{array}$} & Standard & 12.570 & \multirow{2}{*}{-10.078} \\
\hline & Sequential & 20.582 & \\
\hline
\end{tabular}


Table 6 shows the main complaints reported by traffic agents in relation to hearing and general health conditions. The stress is more related complaint $(26.3 \%)$ for subjects with normal hearing, and (18.8\%) for subjects with symptoms suggestive of NIHL. As for the problems with direct action for auditory system, the most reported were: Ear ache and Tinnitus in RE (33.9\%) with normal hearing and tinnitus (50\%) and dizziness (40\%) for those with hearing loss suggestive of NIHL. Another fact that caught our attention was that for subjects with hearing loss, decreased hearing was the complaint less reported $(6.3 \%)$, in agreement with the literature (Bernardi, 2003; Gatto et al., 2005, Gonçalves et al., 2012; Welch et al., 2013).

Table 6. Prevalence of Extra-Auditory and Auditory Complaints Reported by the Traffic Agents, Manaus 2011

\begin{tabular}{|l|c|c|l|c|c|}
\hline \multicolumn{1}{|c|}{ Extra-auditory complaints } & \multicolumn{3}{c|}{ Auditory complaints } \\
\hline \multicolumn{1}{|c|}{ Symptom } & $\begin{array}{c}\text { Case sugges- } \\
\text { tive of NIHL }\end{array}$ & Normal & \multicolumn{1}{c|}{$\begin{array}{c}\text { Case sugges- } \\
\text { tive of NIHL }\end{array}$} & Normal \\
\hline Tiredness & $6.3 \%$ & $13.6 \%$ & $\begin{array}{l}\text { Hearing reduc- } \\
\text { tion }\end{array}$ & $6.3 \%$ & $11 \%$ \\
\hline Discomfort & $12.5 \%$ & $11 \%$ & Otalgia RE & $11.3 \%$ & $33.9 \%$ \\
\hline $\begin{array}{l}\text { Reduction of concen- } \\
\text { tration }\end{array}$ & $12.5 \%$ & $13.6 \%$ & Otalgia LE & $20 \%$ & $30.5 \%$ \\
\hline $\begin{array}{l}\text { Reduction of effi- } \\
\text { ciency }\end{array}$ & $6.3 \%$ & $9.3 \%$ & Otorrhea RE & $12.5 \%$ & $9.3 \%$ \\
\hline Head ache & $6.3 \%$ & $7.6 \%$ & Otorrhea LE & $6.7 \%$ & $7.6 \%$ \\
\hline Stress & $18.8 \%$ & $26.3 \%$ & $\begin{array}{l}\text { Acoustic trau- } \\
\text { ma }\end{array}$ & $18.8 \%$ & $2.5 \%$ \\
\hline Insomnia & $12.5 \%$ & $5.1 \%$ & Dizziness & $40 \%$ & $29.7 \%$ \\
\hline Nervous & - & $11 \%$ & Tinnitus RE & $50 \%$ & $32.2 \%$ \\
\hline Mood swings & $6.3 \%$ & $13.6 \%$ & Tinnitus RE & $40 \%$ & $33.9 \%$ \\
\hline
\end{tabular}

\section{Discussion}

Occupational exposure to urban noise generated mainly the traffic of motor vehicles is a worrying fact in the world modern. However, their effect on the hearing have not been completely determined, since, on the one hand, causes permanent hearing loss are multiple and difficult to control, and secondly, customs and habits of life, living and working in large urban centers, differ greatly from one individual to another.

The extra-auditory complaints reported in this study in increasing order of appearance were stress, fatigue, mood changes, nervousness, insomnia, decreased concentration and yield, headache and stomach ache. Related to hearing complaints for subjects with normal hearing, the most reported were tinnitus, ear pain, dizziness, otorrhea, hearing loss, and acoustic trauma. As for those who had hearing loss, tinnitus, dizziness, and acoustic trauma; and, in smaller numbers, otalgia, otorrhea, and hearing loss. The presence of tinnitus, although has been also the main complaint of individuals with normal hearing, is reported in the literature as common in workers who work in occupational environments with high noise levels, and often associated with the NIHL presence (Caciari et al., 2013; Dias et al., 2006; Servilha\&Delatti, 2012). Another point is the fact that the self-perception of noise reported by subjects demonstrates that 91 consider noise as high, 23 medium and 4 low. Even demonstrating awareness of the risk that they are exposed, few adhere to the use of hearing protection. Another aggravating factor is the fact that there is no hearing conservation program geared to these workers.

Exposure to continuous noise of $85-90 \mathrm{~dB}$, particularly over a lifetime in industrial settings, can lead to a progressive loss of hearing, with an increase in the threshold of hearing sensitivity (Kang et al., 2013). The variable occupational noise exposure showed statistically significant correlation with the auditory thresholds for both ears and with the tritonal average of high and low frequencies. This finding was also described by other studies as Lopes (2009), and Gatto et al. (2005).Occupational noise exposure also shows some association with raised blood pressure (Babisch et al., 2005; Zamanian et al., 2013). The effects of noise are strongest for those outcomes that, like annoyance, can be classified under quality of life as important fact that has direct actuation on illness.

Available data on NIHL prevalence give a partial view of the risk related to hearing loss. Lobato (1998) evaluated 130 traffic operators from Traffic Engineering Company (CET), São Paulo-SP, and found that $31.16 \%$ had abnormalities suggestive of NIHL in at least one ear. Barbosa (2001) analyzed audiograms of workers relating to the road traffic in São Paulo, and found $28.5 \%$ of audiometric curves suggestive of NIHL. The estimated prevalence of NIHL in sequential tests in this study was $20.5 \%$ for the RE, and $19.2 \%$ for the LE. When stratified in length of service in the function was found a larger number of subjects for time intervals of 6-10 years of exposure for both ears. Guerra et al. (2005) investigated the prevalence of cases suggestive of NIHL at a metalworking in Rio de Janeiro, aged from nineteen to seventy years. The results 
reveal that the cases suggestive of NIHL rise from six years in length of service in the function.

Corroborating the results of this research, it was observed, also, that the data collected by workers who already have some type of unilateral or bilateral hearing loss affirm have good hearing $(40 \%)$ in RE, and $(50 \%)$ in LE, even with apparent injury audiological, did not complain of hearing difficulties. Oton et al. (2008) when comparing audiograms of workers exposed to occupational noise with self-reported hearing, observed that the hearing referred as good wasn't compatible with hearing impairment present in audiometric tests, indicating that workers did not understand their hearing difficulty. It is believed that this may be explained by the fact of NIHL starts at acute frequencies, and in many times, the individual does not imagine that not understand what is being said, associating the lack of attention and not to hearing loss. Lopes(2009)argues that the emergence of symptoms are delayed and insidious, which leads workers not realize early the hearing damage.

Traffic noise is the most important source of environmental annoyance. Severe annoyance persistent over prolonged periods is to be regarded as causing distress. Therefore, a radical change of attitude, a change of paradigm is necessary. For an immediate triggering of protective reactions the information conveyed by noise is very often more relevant than the sound level. However, its effect on hearing has not yet been fully determined, since, on the one hand, the causes of permanent hearing loss are multiple and difficult to control, and secondly, the habits and customs of life who live and work in urban centers, differ greatly from one person to another. Thus, protective measures of hearing health promotion and / or hearing loss prevention should be emphasized. The results of this study show the relationship between noise pollution and hearing health, with preoccupying prevalence of this fact on traffic agents from Manaus-AM. The study aims with these findings, sensitize managers on the need to ensure the right to health and safety at work, subsidizing policies on worker health. It is intended, also, to highlight the need to promote environmental education strategies in order that excessive noise produces harmful effects on the human body, constituting a public health problem.

\section{Acknowledgment}

Authors are indebted to Municipal Institute of Traffic Engineering and Control (MANAUSTRANS).

\section{References}

Azevedo, A. P. (1993). Ruído - um problema de saúde pública (outros agentes físicos). In: J.T.P.Buschinelli, L.E. Rocha, R.M. Rigotto(Orgs). Isto é trabalho de gente? Vida, doença e trabalho no Brasil. São Paulo: Vozes.

Babisch, W., Beule, B., Schust, M., Kerstenand, N., Ising, H. (2005). Trafficnoiseand risk of myocardial infarction.Epidemiology, 16(1), 33-40.

Barbosa, A. S. M. (2001). Ruído urbano e perda auditiva: o caso da exposição ocupacional em atividades ligadas à coordenação do tráfego de veículos no município de São Paulo [dissertação]. São Paulo: Faculdade de Saúde Pública, Universidade de São Paulo, 2001.

Barregard, L., Bonde, E., \& Ohrström, E. (2009). Risk of hypertension from exposure to road traffic noise in a population-based sample.Occup. Environ. Med., 66(6), 410-415.

Botteldooren, D., Dekoninckand, L., Gillis, D. (2011). The influence of traffic noise on appreciation of the living quality of a neighborhood.Int. J. Environ. Res. Public Health, 8(3), 777-798.

Brazil, IBGE, Brazilian Institute of Geography and Statistics, www.ibge.gov.br/catálogos/indicadores, 2012.

Caciari, T., Rosati, M. V., Casale, T., Loreti, B., Sancini, A., Riservato, R., Nieto, H. A., Frati, P., Tomei, F., \& Tomei, G. (2013). Noise-induced hearing loss in workers exposed to urban stressors.Sci.Total Environ.,463-464C, 302-308.

Cordeiro, R., Clemente, A. P. G., Dinizand, C. S., Dias, A. (2005). Exposição ao ruído ocupacional como fator de risco para acidentes do trabalho. Revista de Saúde Pública, 39(3), 461-466.

Dias, A., Cordeiro, R., Correnteand, J. E., Gonçalves, C. G. O. (2006). Associação entre perda auditiva induzida pelo ruído e zumbido. Cadernos de Saúde Pública, 22(1), 63-68.

Forattini, O. P. (1991). Quality of life in an urban environment: S. Paulo city, Brazil. Revista de Saúde Pública, 25(2), 75-86.

Ferreira, M. Jr.Perda auditiva induzida pelo ruído: bom senso e consenso. São Paulo: VK, 1998

Gatto, C. I., Lermen, R. A., Teixeira, T. M., Magni, C., \& Morata, T. C. (2005). A análise da conduta de médicos do trabalho diante de trabalhadores com perda auditiva. Distúrbios da Comunicação, 17(1), 1001-1115.

Goncalves, C. G. O., Marques, J. M., Ribas, A., Lacerda, A. B. M., Lobato, D., Costaand, G. L., Goncalves, G. (2012). Caracterização dos limiares auditivos de odontólogos numa população da cidade de Curitiba PR, Brasil. International Archives of Otorhinolaryngology, 16, 824-833.

Gozalo, G. R., Morillas, J. M., \& Escobar, V. G. (2013). Sci Total Environ., 6(461-462C), 453-461.

Guerra, M. R., Lourenço, P. M. C., Teixeiraand, M. T. B., Alves, M. J. M. (2005). Prevalência de perda auditiva induzida por ruído em empresa metalúrgica. Revista de SaúdePública, 39(2), 238-244.

Kang, T. S., Lee, L. K., Kang, S. C., Yoon, C. S., Park, D. U., \& Kim, R. H (2013). Assessmentofnoisemeasurements made with acontinuousmonitoring in time.J.Acoust. Soc. Am., 134(1), 822-831.

Lobato, D. C. B. (1998). Incidência de perdas auditivas induzidas pelo ruído em trabalhadores (operadores de tráfego) da Companhia de Engenharia de Tráfego (CET). São Paulo: Curso de Aprimoramento - USP, 1998.

Lopes, A. C. (2009). Condições de Saúde Auditiva no Trabalho: Investigação dos Efeitos Auditivos em Trabalhadores Expostos ao Ruído Ocupacional. Arquivos Internacionais de Otorrinolaringologia, 13(1), 49-54.

Minayo, M. C. S., Hartz, Z. M. A., \& Buss, P. M. (2000). Qualidade de vida e saúde: um debate necessário. Ciência \& Saúde Coletiva, 5(1), 7-18.

Ministério do Trabalho. Portaria n ${ }^{\circ} 19$ GM/SSSTb, de 9 de abril de 1998. Estabelece diretrizes e parâmetros mínimos para avaliação e acompanhamento da audição em trabalhadores expostos a níveis de pressão sonora elevados. Diário Oficial da União, São Paulo, 22 abril, 1998.

Nunes, M. (2006). Uma breve visão sobre o ruído urbano. Educação \& Tecnologia, 1(2), 135-146.

Oliveira, E. B., \& Lisbon, M. T. L. (2007). As representações sociais do ruído pelos trabalhadores de enfermagem de um centro de terapia intensiva. Enfermagem, 15(4), 495-501.

Oton, A., Boger, M. E., Anadergh, B. B., Shimizu, H. E., \& Maftum, M. A. (2008). Ruído Ocupacional como fator de risco para perda auditiva. Cogitare Enfermagem, 13(3), 367-373.

Servilha, E. A., \& Delatti, M. A. (2012). Noise perception in the workplace and auditory and extra-auditory symptoms referred by university professors.J. Soc. Bras. Fonoaudiol. 24(3), 233-238.

Stansfeldand, S. A., Matheson, M. P. (2003). Noise pollution: non-auditory effects on health. British Medical Bulletin, 68, 243-257.

Welch, D., Shepherd, D., Dirks, K. N., McBrideand, D., Marsh, S. (2013). Road traffic noise and health-related quality of life: A cross-sectional study.Noise Health, 15(65), 224-230.

World Health Organization. Reportofthe InformalWorkingGrouponPreventionofDeafnessandHearingImpairmentProgrammePlanning. Geneva: WHO, 1991. 
World Health Organization. WHO Guidelines for Community Noise Report. Urban streets functionality as a tool for urban pollution management.Geneva: WHO, 1999.

World Health Organiza-

tion.Gradesofhearingimpairment<http://www.who.int/pbd/deafness/he aring_impairment_grades/en/index.html>. Geneva: WHO, 2009.
Zamanian, Z., Rostami, R., Hasanzadeh, J., \& Hashemi, H. (2013). Investigation of the effect ofoccupational noise exposure onbloodpressureand heart rate of steel industry workers.J. Environ. Public Health, 2013, doi: $10.1155 / 2013 / 256060$ 